\title{
Table of Contents
}

Margaret McCarthy

Introduction - 1

\section{Section 1: Historical Roots and Official Stories}

Enno Stahl

An Alternative History of Pop - 31

Sabine von Dirke

Under Construction: Andreas Neumeister's Pop Modern

Historiographies -53

\section{Section 2: Alternative Voices and Vantage Points}

Hester Baer

The Pop-Nostalgia of Sven Regener and Leander Haußmann - 79

Claudia Breger

Pop-Cultural Camera Interventions: Kanak TV — 101

\section{Section 3: Pop and Gender}

Molly Knight

Bodily Harm: Pop Masculinity in Benjamin Lebert's Crazy and Der Vogel ist ein Rabe -123

Emily Spiers

'There's No Lobby for Girls in Pop': Writing the Performative Popfeminist

Subject -143

Corinna Kahnke

Generation Golf Meets Zonenkinder: Gender, (N)ostalgia and the Berlin Republic -167 
VI _ Table of Contents

Section 4: Pop in the New Millennium

Gillian Pye

The Party's Over: PeterLicht and the End of Capitalism -187

Gary Schmidt

Fear of the Queer? On Homosexuality, Masculinity and the Auratic in Christian

Kracht's Anti-Pop Pop Novels — 209

Carrie Smith-Prei

'Pop Eats Itself': Crisis Discourse, the Literary Market and Pop Performance in Joachim Lottmann's Novels — 237

Thomas Ernst

Pop vs. Plagiarism: Popliterary Intertextuality, Staged Authorship and the Disappearance of Originality in Helene Hegemann — 263

Pop Literature: A Bibliography — 285

Index 299 